\title{
Lesbianidades em São Paulo (1940-2000):
}

\author{
Breve panorama
}

\author{
Aline Amorim de Assis ${ }^{1}$ \\ Fernanda Elias Zaccarelli Salgueiro ${ }^{2}$ \\ Nayla Tavares Guerra ${ }^{3}$ \\ Rita Cerqueira Quadros ${ }^{4}$
}

Resumo: O presente artigo almeja investigar o surgimento e a consolidação do movimento de lésbicas em São Paulo, partindo de alguns marcos históricos nos campos artístico, jornalístico, social e político que vão desde 1940 até o início dos anos 2000. Objetiva-se contribuir para o aumento da produção e difusão de informações sobre o contexto no qual se deu parte da reprodução do imaginário sobre a lesbianidade e a constituição da lésbica enquanto sujeito sociopolítico no espaço urbano. O texto foi construído por meio de fontes primárias (matérias de jornal, obras artísticas), publicações de entrevistas com militantes e produções acadêmicas sobre os temas abordados.

Palavras-chave: Lesbianidades; Imaginários; História; Sujeito coletivo; Lutas sociais.

\section{Introdução}

Neste artigo panorâmico, apontamos alguns marcos históricos da constituição e emergência do movimento de lésbicas em São Paulo em momentos do século XX. Tomase a década de 1940 para destacar as dificuldades de tomada do espaço público, abarcando a emergência de um novo sujeito político no Brasil em fins dos anos 1970 e começo dos anos 1980, e os desdobramentos desse acontecimento até o término de nosso recorte

\footnotetext{
${ }^{1}$ Graduanda no Curso Superior do Audiovisual, ECA-USP. E-mail: aline_aassis@usp.br.

2 Doutoranda em Filosofia, FFLCH-USP. E-mail: fernanda.salgueiro@usp.br.

${ }^{3}$ Graduanda no Curso Superior do Audiovisual, ECA-USP. E-mail: naylaguerra@usp.br.

${ }^{4}$ Socióloga, Fundação Escola de Sociologia e Política de São Paulo. E-mail: ritacerquadros@gmail.com.
}

Vol. 03, N. 11, Jul. - Set., 2020 - http://periodicoscientificos.ufmt.br/ojs/index.php/rebeh/index 


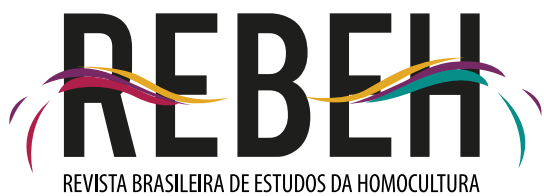

temporal, nos anos 2000. O texto foi construído por meio de fontes primárias (matérias de jornal, obras artísticas), publicações de entrevistas com militantes e produções acadêmicas sobre os temas abordados.

\section{Um imaginário pra chamar de seu}

No campo das artes, a década de 1940 provocou abalos significativos à moralidade estabelecida. Nelson Rodrigues, o "autor maldito", como viria a ser taxado, escancarou a hipocrisia da família burguesa decadente e a fragilidade dos imperativos morais diante dos impulsos sexuais. Nas cenas iniciais da peça teatral Vestido de Noiva (1943), o autor insere, no plano das alucinações da personagem Alaíde, "uma vaga sugestão lésbica" provocada pela dança de duas prostitutas em um bordel (RODRIGUES, 2017 [1943], p. 164). O sucesso obtido com esta obra foi perdido nos trabalhos seguintes, a começar por Álbum de Família (1946), que permaneceu censurado até 1965 (embora circulasse na forma de livro), em razão da explicitação de relações proibidas, como o incesto. No primeiro ato da peça, duas garotas se beijam no interior de um internato de freiras após jurarem amor e fidelidade eternos. Ao regressar ao núcleo familiar, uma delas, Glória, demonstra ao público sua paixão pelo pai (RODRIGUES, 2017 [1946], p. $562-563)$.

Dois anos depois do lançamento de Álbum de Família, em 1948, foi lançado o filme comercial Poeira de Estrelas, dirigido por Moacyr Fenelon e produzido pela Cinédia. A obra aborda a afetividade de duas cantoras que só ousam dizer o que sentem na moldura da representação performática - quando se expressam pelas músicas e enredo levado a cabo no palco. Ao final, é como se tudo não passasse de uma amizade com cores vívidas, sobretudo diante do casamento bem-sucedido de uma delas com o futuro dono do teatro. Agora, enfim, as relações entre mulheres não ocupavam mais (apenas) as páginas de livros de criminologia ou medicina: um novo lugar foi conquistado, ainda que caracterizado pela efemeridade, pelo anonimato e pelo simulacro de uma relação heterossexual feliz.

Por isso mesmo, um dos eventos de maior importância para a constituição da lesbianidade enquanto identidade social foi a construção de um imaginário proporcionado 
pela literatura. Ao publicar Volúpia do Pecado e Carne em Delírio, em 1948, quando ainda era adolescente, a escritora Cassandra Rios (1932-2002) inaugurou uma produção literária popular com inovações que educariam toda uma geração (PAIVA, 2002). Seus 50 livros retratam mulheres com desejo sexual afirmativo, rompendo com a imagem tradicional da mulher passiva, maternal e romântica, bem como com as narrativas da "amiga" que jamais consumaria seus desejos momentâneos e não-ditos.

Sua obra forneceu informações sobre a sexualidade feminina (o que era então raro) e sobre as dores e delícias de ser lésbica, favorecendo uma visibilidade até então inédita na opinião pública (KORICH apud ANGELO, 2013). E isso não apenas por sua participação (discreta, porém evidente) nos meios de comunicação de massa, como a televisão, mas sobretudo porque apesar dos 36 livros censurados pela ditadura militar, a "papisa da homossexualidade" ou a "Safo de Perdizes", como era chamada, foi a primeira escritora a vender mais de 1 milhão de livros no país, superando outros autores bastante populares à época, como Clarice Lispector, Jorge Amado e Érico Veríssimo. As teses judiciais mobilizadas contra sua obra baseavam-se nas acusações de imoralidade e aliciação à homossexualidade.

Por onde andavam as lésbicas por estas décadas? Certamente, não no cotidiano visível do espaço público. É o que Cassandra Rios relata na voz de Flávia, em Eu sou uma lésbica (1979):

\footnotetext{
Entendi desde então por que lésbicas genuínas como eu andam sós, escondemse, têm medo de travar novas relações, evitam certos ambientes e formam pequenos grupos que se refugiam em apartamentos quando querem se distrair, jogando, batendo papo, numa festinha comum como a de qualquer família respeitável (RIOS, 2006 [1979], p. 93).
}

Restava às lésbicas a reclusão da vida doméstica, redes de amigas, raros espaços religiosos (eles mesmos marginalizados), cantos escuros da cidade (como alguns bares descritos à frente) e o silêncio da noite. É a partir dessa experiência de uma existência simbólica e social limitada que vai surgir a demanda por visibilidade do movimento.

Mas é também preciso mais uma vez lembrar que o contexto no qual as mulheres estavam inseridas, de modo geral, já não lhes permitia liberdades. O direito ao voto havia sido conquistado em 1932 e a luta pela igualdade civil continuava. Apesar de todos os 
debates da década de 1950, a legislação manteve a previsão de heterossexualidade compulsória e a institucionalização do patriarcado, que retiravam a autonomia de todas as mulheres. Foi apenas com o Estatuto Civil da Mulher Casada (Lei $n^{\circ} 4.121$ de 1962) que se reconheceu às mulheres a capacidade civil plena: a partir de agora elas podiam trabalhar fora de casa sem pedir autorização ao marido, fazer contratos de compra e venda de imóveis, receber herança. O marido continuava como o "chefe da sociedade conjugal", mas a mulher se tornava uma reconhecida "colaboradora" pela nova redação do art. 233 do Código Civil ${ }^{5}$ (BARSTED; GARCEZ, 1999, p. 19 e ss.).

Não espanta, portanto, o silêncio acerca da sexualidade de nomes importantes da música popular brasileira, como o das cantoras e compositoras Tuca (1944-1978) e Marília Medalha (1944-). Tuca lançou os álbuns Meu eu (1966), Tuca (1968), La Question (1971) com a cantora francesa Françoise Hardy e Dracula I love you (1974) este último, com uma marca experimental elaborada, contém a canção "Girl”, com eulírico que pede: "Girl, / pega sua roupa de pirata azul / e venha ficar comigo". Nos primeiros anos, Tuca tinha como duas parceiras musicais Consuelo de Castro e a cineasta Rita Moreira, talvez a primeira brasileira a produzir um curta-metragem sobre lésbicas, junto a sua companheira afetiva e criativa, Norma Bahia Pontes ${ }^{6}$. Marília Medalha atuou em 1965 na peça Arena Conta Zumbi, de Augusto Boal e Gianfrancesco Guarnieri, obtendo o prêmio APCA como Atriz Revelação do ano. Foi, junto com Edu Lobo, vencedora do III Festival de Música Popular Brasileira da TV Record (1967) pela interpretação de "Ponteio", no mesmo ano em que gravou seu primeiro LP, homônimo. Revelou sua profundidade como compositora no excepcional álbum Caminhada (1972).

Em 1973, Chico Buarque e Ruy Guerra escreveram Calabar: o elogio da traição. A peça foi censurada sob acusação de imoralidade e de desrespeito à narrativa colonial portuguesa, mas Chico Buarque lançou parte das músicas, com letras

\footnotetext{
${ }^{5}$ Art. 240 da Lei no 4.121/62 - "A mulher assume, com o casamento, os apelidos do marido e a condição de sua companheira, consorte e colaboradora dos encargos da família, cumprindo-lhe velar pela direção material e moral desta".

${ }^{6}$ Rita Moreira e Norma Bahia Pontes são brasileiras pioneiras na direção de vídeos independentes e na produção audiovisual feita por e sobre lésbicas. Migraram juntas, na década de 1970, para os Estados Unidos, onde se aproximaram tanto da militância lésbica e feminista, como da tecnologia do videotape. Grande parte do trabalho da dupla está acessível no canal do Youtube de Rita Moreira, disponível em: $<$ https://www.youtube.com/user/ritascmoreira2/videos $>$ Acesso 07 dez. 2020. Para mais informações sobre Moreira e Pontes, consultar Perez (no prelo).
}

Vol. 03, N. 11, Jul. - Set., 2020 - http://periodicoscientificos.ufmt.br/ojs/index.php/rebeh/index 
modificadas, no LP Chico Canta (1973). A música "Bárbara", que na sua versão original era um dueto cantado pelas tórridas personagens Bárbara e Anna de Amsterdam, foi parcialmente vetada. Em certa passagem, Anna se declarava: "Vamos ceder enfim à tentação de nossas bocas cruas / E mergulhar no poço escuro de nós duas". A censura vetou a expressão "nós duas", enfraquecendo a conotação homossexual da letra (ALCÂNTARA, 2011, p. 105). Na gravação, Chico Buarque cantou os versos de ambas personagens, o que também reduziu a tensão moral da obra.

Apesar deste e de outros episódios de censura, é nesta década de 1970 que o jogo começa a virar. As propostas jurídicas do movimento feminista pululam no Congresso Nacional e uma delas emplaca, substanciando a Lei do Divórcio (Lei n ${ }^{\circ}$ 6.515/1977). Ensaia-se uma saída do armário - agora não de uma artista específica, mas de dezenas de mulheres comuns de São Paulo. O curto espaço do carnaval, entre a segunda e a quartafeira de cinzas, passou a representar um portal de expressão dos desejos reprimidos, um tempo-espaço para vestir suas fantasias, colocá-las na rua à luz do dia - e só tirá-las nos toaletes... Como nos conta Cassandra Rios:

\begin{abstract}
Naquele tempo, as mulheres aproveitavam o carnaval para usar suas calças compridas, camisas, gravatas, caracterizando-se de homem para serem melhor identificadas pelas outras mulheres, as "passivas". O carnaval nos clubes marcava momentos grandiosos na vida das lésbicas, que se fantasiavam de Zorro, de caubói, usavam máscaras, cortavam os cabelos rente na nuca, riscavam bigodes com lápis de sobrancelhas e até costeletas. Era a liberdade. (...) A orquestra atacava os sambas e marchas, as serpentinas riscavam o ar, confetes atapetavam o chão, e as lésbicas confinavam-se no toalete. E para lá iam, atraídas, as que tinham tendências para eclodir durante os três maravilhosos dias festivos (RIOS, 2006 [1979], p. 95-96).
\end{abstract}

É neste momento, aliás, que a marcha "Maria Sapatão" de João Roberto Esteves Kelly ganhou imensa repercussão. Na sua primeira versão, Maria Sapatão é um dia Maria, no outro dia, João, e o eu-lírico defende a moça: "Sapatão é um sucesso / tá cheia de tutu / quem não curtir / essa Maria / que vá chupar caju”. A letra foi censurada pelos militares em agosto de 1980, aprovando-se apenas a que propunha que Maria Sapatão "de dia é Maria / de noite é João" (DCDP, 1980). Os censores bem que tentaram empurrar a lesbianidade de volta ao armário, mas a vida social e cultural provava que isso não era mais possível. 
Em 1979, além da publicação de Eu sou uma Lésbica - que, segundo seus críticos, foi a obra mais escandalosa de Cassandra Rios -, testemunhamos o lançamento do LP Simples como Fogo de Marina Lima e o álbum homônimo de Angela Ro Ro. Essas artistas se tornariam ícones assumidamente lésbicas na década de 1980, contestando papéis e padrões de gênero e de sexualidade.

Em suma, eis um índice que traduz o que foi a década de 1970 para as lésbicas: se entre 1900 e o fim da década de 1960 encontramos nos jornais Folha da Manhã, Folha da Tarde e Folha da Noite apenas duas referências às "lésbicas", motivadas pela descrição de uma personagem da peça Huis-Clos de Jean-Paul Sartre, ao longo da década de 1970 o número salta para 280 menções ${ }^{7}$.

No início de 1980, Angela Ro Ro provocava gargalhadas do público ao afirmar ironicamente durante os shows: "Vocês já sabem: eu sou a única cantora lésbica da MPB". O público sabia (ou desconfiava) que muitas das grandes figuras da música popular brasileira, que já era predominantemente feminina, eram lésbicas ou bissexuais não assumidas. A lista abarcava Zizi Possi, Maria Bethânia, Simone, Gal Costa, Joanna, a dupla Luhli e Lucina, Sandra de Sá, Leci Brandão e outras (UM OUTRO OLHAR, 2013). O armário estava em processo de explosão. A importância dessas mulheres para o mundo das artes foi reforçado no especial Mulher 80 da Rede Globo. Ainda, a boa aceitação do seriado Malu Mulher, protagonizado por Regina Duarte e Narjara Duretta, reforçaria a ideia de uma mudança de mentalidade da população.

\section{Uma outra onda de repressão}

Apesar dessas conquistas, estamos falando do período no qual vigorava a ditadura militar. De acordo com a Comissão Nacional da Verdade, “[n]ão houve uma política de Estado formalizada e tão coerente no sentido de exterminar os homossexuais" (BRASIL: CNV, 2014, p. 301), porém houve uma ideologia que justificou o golpe e a perpetuação do regime autoritário, baseada em valores conservadores de moral e bons costumes. A homofobia vigorou dentro de uma visão de Estado, que legitimava a

\footnotetext{
${ }^{7}$ Este dado é o produto da pesquisa realizada pelas autoras no banco de dados destes jornais.
} 
violência e a censura contra pessoas lésbicas, gays, bissexuais e transsexuais (doravante denominadas LGBT). Nesse contexto, destaca-se a citada campanha contra as obras de Cassandra Rios, a artista mais censurada do país durante a ditadura civil-militar (BRASIL: CNV, 2014, p. 305).

A perseguição policial também era utilizada como instrumento de repressão aos grupos considerados marginais, sobretudo LGBTs, prostitutas, negras e negros. Eram realizadas rondas de policiamento nas regiões centrais das grandes cidades brasileiras, com o objetivo de promover uma limpeza moral. Quem não cumprisse os papéis sexuais e de gênero esperados era enquadrado por atentar contra os bons costumes e a ordem pública. Na cidade de São Paulo, sob o comando do delegado José Wilson Richetti ${ }^{8}$, de 300 a 500 pessoas eram levadas por dia para delegacias por estes motivos (BRASIL: CNV, 2014, p. 307).

Paradoxalmente, porém, foi nesse mesmo período que em São Paulo emergiu uma cultura de bares voltados às lésbicas, sendo o "Ferro's Bar" o pioneiro. Lá, essas mulheres podiam se encontrar com seus grupos de amigas, conhecer pretendentes e utilizar o espaço politicamente. Marisa Fernandes, militante lésbica e feminista, descreve detalhes dessa vida noturna:

Você sabe que a noite lésbica era basicamente um quadrilátero do Bixiga, na rua Martiniano Prado ali, que tinha o Ferro's Bar [...], na mesma calçada, um pouco mais pra frente tinha o Cachação [...], tinha um outro na Santo Antônio que era num subterrâneo, o Perepepes. O que que acontecia, esses dois eram de frequentadoras de periferia, eram majoritariamente lésbicas negras [...]. $\mathrm{O}$ Ferro's, como era um restaurante bar, pizzaria e tudo, tinha que pagar [...], mas não era isso também, tinha de tudo quanto era classe social. [...] Um pouco mais pra cima você tinha um lugarzinho chamado Planetas, enfim a gente comia ali e depois descia pra beber, né? Era tudo muito próximo. E boates, tinha a Mistura Fina, inclusive o local onde era a Mistura Fina, na Major Sertório, serviu de sede durante bastante tempo tanto pro LF quanto pro SOMOS fazer reunião. [...] e a Mustache. Assim, o Ferro's, pra mim não tem nada mais extraordinário do que o Ferro's, porque era de lésbicas, era de lésbicas, ponto [...] (MUSEU DA DIVERSIDADE SEXUAL, 2017, parte 4/5).

\footnotetext{
${ }^{8}$ O delegado Richetti assume a delegacia seccional do centro em 1980, durante o governo de Paulo Maluf. As rondas persecutórias a prostitutas e travestis, por ele promovidas, persistem até o início do governo de André Franco Montoro, em março de 1983.
}

Vol. 03, N. 11, Jul. - Set., 2020 - http://periodicoscientificos.ufmt.br/ojs/index.php/rebeh/index 
A polícia empreendia operações violentas justamente nestes bares - Ferro's, Bixiguinha e Cachação, a fim de atacar os pontos de sociabilidade lésbica. Um marco dessas operações policiais é a chamada “Operação Sapatão", ocorrida em 15 de novembro de 1980, quando todas as frequentadoras dos estabelecimentos citados foram detidas sob a alegação "você é sapatão". Ao final, as 200 lésbicas presas tiveram que pagar para serem liberadas (OLIVEIRA, 2017).

Em resposta à ditadura civil-militar, ao conservadorismo vigente à época e às tensões dentro das organizações da esquerda tradicional e do movimento feminista ${ }^{9}$, surge, em 1978, o SOMOS - Grupo de Afirmação Homossexual, considerado um dos primeiros grupos homossexuais politicamente organizados no país (IRE; LENZI; SILVA, 2019). Logo em 1979, sentindo a necessidade de considerar as especificidades das lésbicas, as membras do grupo criam o Grupo Lésbico Feminista (LF), referência de emergência do movimento lésbico brasileiro. Este se inicia como um subgrupo do SOMOS e, em seguida, torna-se independente em 1981, dando origem ao Grupo de Ação Lésbico Feminista (GALF).

No dia 13 de junho de 1980, houve uma unificação de diversos movimentos e pessoas negras, feministas, lésbicas, gays, prostitutas, travestis e estudantes marcharam em um ato político, no centro de São Paulo, contrário à violência perpetuada pelo delegado Richetti. "Essa foi a primeira grande mobilização política do movimento LGBT brasileiro, preconizando as grandes manifestações de rua que posteriormente seriam

\footnotetext{
${ }^{9}$ A maior parte das organizações da esquerda tradicional colocavam a opressão de classe acima das demais formas de injustiça social. Durante a ditadura civil-militar, muitos grupos da resistência viam na homossexualidade um desvio pequeno-burguês ou uma degeneração, motivo pelo qual ativistas como Herbert Daniel se viram na obrigação de "esquecer" seus desejos em prol da revolução (GREEN, 2018). Ao mesmo tempo, seus companheiros Dilma Rousseff e Ângelo Pezzuti, seus confidentes, não o desaprovaram, talvez movidos pelo clima de mudanças de mentalidade em curso. Nas décadas de $1960 \mathrm{e}$ 1970, o próprio feminismo era visto como uma ameaça à unidade da luta da esquerda e como um questionamento à autoridade dos homens que lideravam tais organizações. Todas as formas de politização das relações e da vida privadas eram compreendidas como obstáculos à luta geral, que deveria se dar no espaço público, tal como imaginado pelos cânones revolucionários. Isso não produziu uma aproximação entre feministas heterossexuais e lésbicas de modo automático nas décadas de 1970 e 1980 . Tanto grupos de esquerda quanto coletivos feministas frequentemente se afastaram das pautas lésbicas. No caso das feministas, é como se a associação com as lésbicas e as implicações epistêmicas e polîticas de suas teóricas, críticas da heterosexualidade compulsória, fosse "longe demais". Como afirmam Gilberta Santos Soares e Jussara Carneiro Costa, "os feminismos brasileiros, historicamente, resistiram a incorporar as questões das mulheres lésbicas em sua produção teórica e agenda política, persistindo a lacuna de crítica à heteronormatividade como elemento fundamental na constituição das relações de gênero" (SOARES, G. S.; COSTA, J. C., 2011-2012).
}

Vol. 03, N. 11, Jul. - Set., 2020 - http://periodicoscientificos.ufmt.br/ojs/index.php/rebeh/index 
organizadas nas Paradas de Orgulho LGBT por todo o país" (BRASIL: CNV, 2014, p. 319).

Um dos primeiros espaços a tematizar abertamente a homossexualidade na imprensa brasileira foi a Coluna do meio, de Celso Cury, em 1976. Como consequência, o jornalista foi processado por violar a moral e os bons costumes, provendo a homossexualidade. Contudo, o processo e as ameaças recorrentes do Estado não foram suficientes para impedir a fundação, em 1978, do Lampião da Esquina, um jornal feito por, sobre e para homossexuais. Dentre seus fundadores estão Darcy Penteado, Aguinaldo Silva, Jean-Claude Bernardet, Peter Fly e João Silvério Trevisan. Segundo este último, havia, nas matérias, uma política de resgate à linguagem do gueto, desmistificando e ressignificando termos como "viado", "bixa", "baitola" e "sapata" (USP, 2018). Na 12a edição do periódico Lampião da Esquina, em maio de 1979, as lésbicas do SOMOS foram convidadas para escrever um artigo, que recebeu o nome de "Amor entre mulheres (elas dizem onde, quando, como e porquê)". Entretanto, a participação das mulheres no jornal era pontual e as lésbicas não conseguiam um espaço recorrente. Marisa Fernandes lembra: "Evidentemente fomos esmagadas. Estávamos em 10 lésbicas e 80 gays" (FERNANDES apud PACOR, 2018).

Cria-se, então, o Chanacomchana em 1981, considerada a primeira publicação ativista lésbica no Brasil (OLIVEIRA, 2017). O jornal circulou até 1987, sendo produzido inicialmente pelo LF e, em seguida, pelo GALF. Um dos espaços de distribuição do Chanacomchana era o Ferro's Bar, um ponto de encontro para lésbicas desde o início da década de 1960. O local passou a receber também ativistas do movimento de mulheres lésbicas no início dos anos 1980, sobretudo aquelas ligadas ao GALF e ao Chanacomchana. Contudo, em meados de 1983, o proprietário tentou barrar a venda do jornal no bar, o que fez com que as lésbicas organizassem o chamado “Levante do Ferro's Bar”. No dia 19 de agosto de 1983, lésbicas e gays entraram no estabelecimento após uma manobra sagaz contra o segurança: uma pessoa jogou seu chapéu para dentro do bar e foi buscá-lo, abrindo passagem para o restante das manifestantes. Foi então que Rosely Roth, uma das precursoras da organização lésbica no Brasil, leu um manifesto. A vitória foi tão importante que a data do evento foi, em 2008, estabelecida como o Dia Nacional do Orgulho Lésbico. 
Em 1984, é lançado Amor Maldito, que pode ser considerado um marco do cinema brasileiro, ainda que durante décadas tenha ficado no ponto cego da historiografia. Trata-se do primeiro longa-metragem de ficção dirigido por uma mulher negra no Brasil, Adélia Sampaio. Ela inovou ao trazer o olhar de uma mulher para a representação da lesbianidade, que até então havia ficado a cargo de cineastas homens. A obra é baseada em fatos reais e retrata o julgamento de Fernanda, acusada de matar Suely, sua exnamorada. Durante sua produção, o órgão estatal responsável por financiar filmes à época, Embrafilme, "reduziu o orçamento até chegar ao ponto de vetar por completo o filme alegando que jamais poderia produzir panfletagem à homossexualidade" (BRASIL, 2016 apud SACRAMENTO, 2017, p. 5). Diante da recusa dos cinemas em exibir um filme com temática lésbica, ele só pode ser distribuído como um pornô, ainda que o erotismo não fosse o foco do filme.

Frente à possibilidade da criação de uma nova Constituinte, de 1985 a 1987 o GALF utilizou o espaço do Chanacomchana para debater a importância de uma política pensada para os direitos homossexuais, sobretudo em textos escritos por Rosely Roth. Ela enfatizava a importância do voto em parlamentares que estivessem atentos à causa homossexual nas eleições de 1986. Juntamente com o Grupo Gay da Bahia e o Triângulo Rosa, o Chanacomchana enviou uma proposta à Constituinte para incluir dentre as hipóteses de discriminações proibidas pela nova Carta aquela por "orientação sexual" e a previsão de uma pena em caso de violação (CHANACOMCHANA, 1986, p. 12-13). Apesar dos esforços de mobilização, que ampliaram o empoderamento e a visibilidade do movimento, não houve resultados expressivos nas urnas ou no texto constitucional. Vigoravam estigmas sociais atrelados à Síndrome da Imunodeficiência Adquirida - Aids, à visão da homossexualidade como uma enfermidade e aos usos que se poderia fazer da expressão “orientação sexual”, escusas utilizadas para argumentar contra a inclusão da proibição da discriminação a homossexuais (SILVA, 2014; SALES, 2019). Refletindo sobre esse processo, Rosely Roth escreveu um balanço na última edição do Chanacomchana, que termina assim: "eu digo para as mulheres lésbicas: sem uma organização coletiva, as nossas propostas dificilmente terão um alcance social sequer razoável" (CHANACOMCHANA, 1987, p. 22). 
A institucionalização do movimento

No período de abertura democrática e com o surgimento da Aids, chamada errônea e preconceituosamente de "peste gay", encerra-se, nos anos 1980, o período do movimento homossexual caracterizado por uma pauta organizativa antiautoritária e comunitarista, de grupos concentrados no eixo São Paulo-Rio-Bahia. Para os contemporâneos, anunciava-se um declínio do movimento, que na década seguinte se transformou em "reflorescimento". Os dados compilados dos encontros nacionais do movimento homossexual assinalam um aumento significativo da quantidade de grupos participantes (FACCHINI, 2003, p. 105 e 111).

Em 1993, a organização do $7^{\circ}$ Encontro Brasileiro de Lésbicas e Homossexuais (Cajamar, SP, 1993) foi palco de intensa discussão entre militantes pois, desde sua criação, o evento era denominado Encontro Brasileiro de Homossexuais - EBHO, e as militantes lésbicas argumentavam que lésbicas não são homossexuais, que a referência invisibilizava a lesbianidade. No próprio encontro, através de votação, foi alterando o nome da atividade. Participaram coletivos de Estados até então sem representantes, como Rio Grande do Sul e Minas Gerais, com um crescimento da participação de coletivos lésbicos de São Paulo, que procurarão inserir as questões de gênero e de visibilidade lésbica no debate (FACCHINI, 2003, p. 105 e ss.).

Do $8^{\circ}$ Encontro Brasileiro de Gays e Lésbicas (EBGLT, Curitiba, 1995) em diante, os eventos passam a obter financiamento de agências governamentais de combate às Infeções Sexualmente Transmissíveis/Síndrome da Imunodeficiência Adquirida (IST/Aids), que buscam parcerias Estado-sociedade civil. Estas atividades passam "a ocorrer paralelamente aos encontros nacionais de 'gays e lésbicas que trabalham com AIDS"” (FACCHINI, 2003, p. 109). Posteriormente, foi adicionada a palavra "travestis" ao nome do evento, marcando, pela primeira vez, a presença de travestis e transexuais na organização, aumentando o leque de demandas a serem discutidas. Naquele mesmo ano seria fundada a Associação Brasileira de Gays, Lésbicas e Travestis (ABGLT).

A possibilidade de obtenção de financiamento público e particular levou alguns coletivos a processos de institucionalização - cujo modelo, no limite, encontrava-se na estrutura empresarial - que resultaram na transformação de grupos em Organizações Não- 
Governamentais (Ongs), com forte divisão e especialização de funções, a corrida por editais e a busca por resultados materiais. O único grupo de São Paulo do início dos anos 1980 que chegou à primeira década dos anos 2000 foi o antigo GALF, que em 1989 se converteu em Ong, tornando-se Rede de Informação Um Outro Olhar. A rede atuou como mídia impressa até 2003 e depois continuou como revista virtual atualizada pela ativista Míriam Martinho.

O encontro seguinte, $9^{\circ}$ EBGLT e $2^{\circ}$ EBGLT-AIDS (São Paulo, 1997), trouxe para a arena ativistas independentes, assessores legislativos e acadêmicos. Em 1998, a ABGLT reunia 68 grupos do movimento homossexual brasileiro, sendo $4 \%$ do Norte, $12 \%$ do Centro-Oeste, $14 \%$ do Sul, $26 \%$ do Nordeste e $44 \%$ do Sudeste. Desses 30 grupos do Sudeste, 18 (60\%) eram de São Paulo, o equivalente a 26\% dos grupos cadastrados do país (FACCHINI, 2003, p. 111-112).

O movimento de mulheres lésbicas também pensou novas formas de articulação nacional e de reivindicação política, em resposta à persistente invisibilidade, inclusive dentro do movimento $\mathrm{GLS}^{10}$ ou $\mathrm{GLBT}^{11}$, e de políticas públicas - ao contrário do que se deu com a agenda das $\operatorname{DST}^{12}$, atualmente denominadas IST $^{13}$, bastante focadas na questão do $\mathrm{HIV}^{14}$. Como resposta a isso, destacamos aqui a criação do SENALE ${ }^{15}$, da $\operatorname{LBL}^{16}$ e da Caminhada Lésbica de São Paulo. É importante apontar que, na sua trajetória, essas organizações foram disputadas por pautas as mais diversas, como religião, questões de raça, classe e demais interseccionalidades.

A realização do I SENALE, em 1996, aconteceu dentro do contexto da necessidade de falar sobre saúde das mulheres lésbicas e bissexuais. A vivência militante dava conta de relatos sobre insegurança, medo e vergonha para procurar atendimento de saúde de tal forma que estas mulheres estavam totalmente excluídas dos serviços de

\footnotetext{
${ }^{10}$ Sigla utilizada para denominar Gays, Lésbicas e Simpatizantes.

${ }^{11}$ Sigla utilizada para denominar Gays, Lésbicas, Bissexuais e Transsexuais. Na I Conferência Nacional de Gays, Lésbicas, Bissexuais, Travestis e Transexuais, realizada em Brasília em 2008, por pressão do movimento lésbico, a sigla foi alterada para que a letra L conquistasse mais visibilidade, vindo na frente do $\mathrm{G}$.

${ }^{12}$ Sigla utilizada para denominar Doenças Sexualmente Transmissíveis.

${ }^{13}$ Sigla utilizada para denominar Infecções Sexualmente Transmissíveis.

${ }^{14}$ Sigla utilizada para denominar a síndrome da imunodeficiência adquirida.

${ }^{15}$ Sigla utilizada para denominar Seminário Nacional de Lésbicas.

${ }^{16}$ Sigla utilizada para denominar Liga Brasileira de Lésbicas.
}

Vol. 03, N. 11, Jul. - Set., 2020 - http://periodicoscientificos.ufmt.br/ojs/index.php/rebeh/index 
saúde. Além disso, se o HIV em um primeiro momento gerou forte estigma, depois ele passou a ser o tema concentrador da atenção à "saúde homossexual". Por outro lado, percebeu-se que quando a mulher sai do escopo de jovem e reprodutora ela não é reconhecida por quem pensa e executa as políticas públicas. Desde então este Seminário acontece regularmente em estados que se responsabilizam por sua organização. Desde 2014 o encontro alterou seu nome para SENALESBI ${ }^{17}$, garantindo a visibilidade e o espaço político para as mulheres bissexuais.

O V SENALE aconteceu em São Paulo em junho de 2003 e implementou uma nova forma de organização da atividade. Até então um grupo se responsabilizava pela organização, mas, desta vez, foi instituída uma Comissão Organizadora Colegiada que era composta não apenas por grupos, mas por militantes que não estavam organizadas dentro de grupos, mas que pretendiam contribuir com a construção da atividade. Esta nova configuração proporcionou a ampliação da representatividade lésbica bem como tirou a marca de que havia donas do movimento de lésbicas. Outra marca importante do V SENALE foi a articulação da LBL, que havia sido criada no Fórum Social Mundial no início do mesmo ano. A LBL surgiu como um espaço de articulação das lésbicas em nível nacional e tem por objetivo fortalecer a organização e empoderamento lesbiano de maneira autônoma e independente.

A I Caminhada de Lésbicas também aconteceu em São Paulo em 2003 e buscava garantir visibilidade política para pauta das mulheres lésbicas e bissexuais, que ficavam totalmente invisibilizadas durante a semana da Parada do Orgulho LGBT ${ }^{18}$ e no evento em si. A I Caminhada, iniciativa do Grupo Umas \& Outras, encerrou o V SENALE, que neste ano foi organizado em São Paulo. Sua Comissão Organizadora enfrentou forte questionamento por parte da Organização da Parada GLBT e de algumas militantes lésbicas que compunham a organização do V SENALE, sob o argumento de que um evento paralelo dividiria o movimento, que começava a ter maior aceitação da sociedade.

\footnotetext{
17 Sigla utilizada para denominar Seminário Nacional de Lésbicas e Bissexuais.

${ }^{18}$ Em 1997, na sua primeira edição, a Parada de São Paulo foi denominada Parada do Orgulho Gay. Dois anos depois, o nome foi alterado para Parada do Orgulho GLBT e, apenas em 2008, se torna Parada do Orgulho LGBT. A instituição organizadora, contudo, mantém no seu nome a designação GLBT (Associação da Parada do Orgulho GLBT).
}

Vol. 03, N. 11, Jul. - Set., 2020 - http://periodicoscientificos.ufmt.br/ojs/index.php/rebeh/index 
A década de 1990 constituiu, ainda, um momento de diversificação de propostas e abordagens de grupos relacionados à pauta lésbica. Destacamos aqui a criação do Comunicação Mulher (COMULHER), o coletivo que construiu o maior acervo audiovisual sobre organização e atos de lésbicas no Brasil, e que também cuidava de outras lutas e pautas de direitos humanos. O grupo foi formado por um conjunto de mulheres, dentre as quais assinalamos a presença da videomaker Maria Angélica Lemos, realizadora do média Lésbicas no Brasil (2004). Ela produziu o primeiro videoclipe sapatão de que temos notícia, com a dupla Bro e Gi, cuja música "Francha com Francha", apesar de finalista, foi proibida pela censura de tocar no Festival Nacional das Mulheres nas Artes (1982), realizado por Ruth Escobar em São Paulo.

Também é importante registrar a criação da editora GLS por Laura Bacellar que dez anos depois fundaria a primeira editora especializada no público composto por mulheres lésbicas, a Brejeira Malagueta (2008-2015) (FSP, 1998). Isso ocorreu no mesmo ano em que se abria a primeira livraria do Brasil voltada ao público LGBT, a Livraria do Meio, que posteriormente veio a ser a Livraria Futuro Infinito (FAU, s/d). A iniciativa cedeu seu espaço para reuniões e eventos ao Grupo Umas \& Outras, um coletivo de lésbicas que surgiria nos anos 2000 com traço intergeracional, diversidade racial e uma estrutura organizativa que garantia biblioteca, rodas conversa, apoio jurídico e psicológico, oficinas artísticas, cineclube, festa mensal e grupos temáticos (maternidade, racismo, envelhecimento), que se manteve a partir da arrecadação entre as frequentadoras e deixou de existir na tentativa de institucionalização.

Nos últimos anos da década de 1990, vislumbra-se a participação de gays e lésbicas nos meios de comunicação, a articulação com associações internacionais de direitos humanos, como a ILGA ${ }^{19}$, o diálogo com parlamentares de todos os níveis da federação para a defesa de projetos antidiscriminatórios e garantidores de direitos, a criação de grupos e organizações locais, estaduais e nacionais (FACCHINI, 2003, p. 85; 111-112).

\footnotetext{
${ }^{19}$ Sigla utilizada para denominar, em inglês International Lesbian and Gay Association (ILGA). Trata-se da Associação Internacional de Gays e Lésbicas, voltada para a promoção e a defesa da igualdade de direitos da comunidade LGBTQIA+ no mundo.
}

Vol. 03, N. 11, Jul. - Set., 2020 - http://periodicoscientificos.ufmt.br/ojs/index.php/rebeh/index 
Considerações finais

Se olharmos para trás, veremos que o século $\mathrm{XX}$ foi palco de mudanças significativas na representação da lesbianidade. Se nas primeiras décadas as práticas sexuais entre mulheres eram inseridas no âmbito do discurso médico e criminal, aos poucos elas se deslocaram para a esfera da imoralidade, adentrando com toda a ambiguidade o mundo da cultura. Teremos aí a reafirmação e a ruptura de preconceitos, a liberação e a censura do imaginário. Com todas as contradições, o teatro, a literatura, a música, o cinema e a televisão darão voz e visibilidade a personagens e ideias vigiadas e apagadas da realidade. Além das obras, que faziam sonhar, o surgimento de artistas (e, depois, militantes) que falavam em primeira pessoa "eu sou uma lésbica" para o grande público - de Cassandra Rios a Angela Ro Ro, Marina Lima e Cássia Eller -, abriu no horizonte a brecha do possível e cimentou as condições para a constituição das lésbicas enquanto sujeitos políticos e de desejo em plena luz do sol. Ao mesmo tempo, ainda que em dimensão muito menor que com os gays (e talvez proporcionalmente à renda), a identidade lésbica foi reforçada pela sua inserção no mercado enquanto segmento consumidor.

Qual é o saldo de tudo isso? Além de ganhos nas liberdades individuais e coletivas, houve avanços na estrutura organizativa pelas regiões do país, com diversidade de pautas e agentes, articulações políticas amplas e algumas vitórias no âmbito do Executivo, de alguns Legislativos municipais e estaduais e do Judiciário. No entanto, a ausência de uma legislação federal e de políticas públicas nacionais que consolidem reivindicações em matéria de emprego, saúde, educação, segurança e assistência, sobretudo em um momento de graves retrocessos de direitos e aumento dos índices de lesbocídio, como o que atravessamos, tem batido à nossa porta.

Por isso, não é possível concluir este artigo sem explicitarmos as contradições entre avanços e exclusões. Se é um fato que muitos passos em direção ao respeito foram dados, não é possível ignorar que as questões de classe e raça/etnia desempenham papel crucial no acesso à cidadania das mulheres lésbicas e bissexuais: nossos avanços não conseguiram interromper o genocídio de mulheres negras, indígenas e pobres lésbicas ou 
bissexuais. O assassinato de Marielle Franco $^{20}$ e de Luana Barbosa ${ }^{21}$, como de tantas outras, pelas mãos da milícia e da polícia, não pode ser esquecido. A luta tem que continuar!

\section{Referências}

ALCÂNTARA, Candice de Morais. Censura e cultura nos anos 1970: o caso de Calabar, de Chico Buarque e Ruy Guerra. Dissertação de Mestrado. UFRGS, Porto Alegre, 2011.

ALVES, Alê. A história de Luana: mãe, negra, pobre e lésbica, ela morreu após ser espancada por três PMs. Ponte Jornalismo, 25 abr. 2016. Disponível em: $<$ https://ponte.org/a-historia-de-luana-mae-negra-pobre-e-lesbica-ela-morreu-apos-serespancada-por-tres-pms/> Acesso em 19 fev. 2021.

ANGELO, Vitor. Documentário retrata Cassandra Rios, escritora lésbica perseguida pela ditadura. Blogay, Folha de S. Paulo, 2013. Disponível em: $<$ https://blogay.blogfolha.uol.com.br/2013/08/04/documentario-retrata-cassandra-riosescritora-lesbica-perseguida-pela-ditadura-militar/> Acesso em jul. 2019.

BARSTED, L.; GARCEZ, E. A legislação civil sobre família no Brasil. In: As mulheres e os direitos civis. Rio de Janeiro: CEPIA, 1999, p. 9-26.

\footnotetext{
${ }^{20}$ Luana Barbosa dos Reis levava seu filho de 14 anos para uma atividade quando foi abordada por policiais militares na cidade de Ribeirão Preto, interior de São Paulo. Ao reivindicar que sua revista fosse realizada por uma policial mulher, foi brutalmente espancada por ao menos seis agentes públicos, segundo testemunhas. Faleceu no hospital, tendo como causa do óbito traumatismo crânio-encefálico. Os policiais alegaram que se defenderam das ofensas de Luana. A acusação contra os policiais foi arquivada pela Justiça Militar no dia 03 de fevereiro de 2017, por "ausência de materialidade delitiva". De acordo com sua irmã, Roseli Barbosa dos Reis, Luana "pagou o preço por parecer um homem negro e pobre, ela foi abordada como outros homens da periferia são. Lésbica, negra e periférica com passagem pela polícia, ela já era considerada culpada" (ALVES, 2016).

${ }^{21}$ Marielle Franco foi a quinta vereadora mais votada para a legislatura carioca de 2016. Eleita pelo Partido Socialismo e Liberdade (PSOL), defendeu uma pauta feminista e pelos direitos humanos. Era a relatora da Comissão Legislativa de monitoramento da intervenção federal no Rio de Janeiro, de que foi crítica, tendo denunciado diversos abusos e crimes cometidos pela Polícia Militar, e inclusive condenado a execução de jovens da periferia às vésperas da sua própria execução. Foi assassinada, com seu motorista, no dia 14 de março de 2018, em um crime com claros sinais de ter sido encomendado. Até hoje, passados mais de mil dias do evento, ainda não há uma resposta conclusiva sobre os mandantes.
}

Vol. 03, N. 11, Jul. - Set., 2020 - http://periodicoscientificos.ufmt.br/ojs/index.php/rebeh/index 
BRASIL, Comissão Nacional da Verdade. Texto 7 - Ditadura e homossexualidades. In:

Relatório: textos temáticos / Comissão Nacional da Verdade. Brasília: CNV, 2014.

CHANACOMCHANA. São Paulo, nº 10, 1986.

. São Paulo, $\mathrm{n}^{\circ}$ 12, 1987.

DCDP - Divisão de Censura de Diversões Públicas. Processo no ${ }^{\circ} 11.958 / 1980$. Arquivo Nacional.

FACCHINI, Regina. Movimento homossexual no Brasil: recompondo um histórico. Cad. AEL, v. 10, n. 18/19, 2003, p. 81-125.

FAU - Faculdade de Arquitetura e Urbanismo (USP). Livraria Futuro Infinito. Outros Urbanismos. Disponível em: <http://outrosurbanismos.fau.usp.br/lugares-memorialgbt-sao-paulo/livraria-futuro-infinito/> Acesso em 15 jun. 2020.

FSP - Folha de S. Paulo. São Paulo tem primeira editora para homossexuais. Folha de S. Paulo. São Paulo, 29 mar. 1998. Disponível em: <https://www1.folha.uol.com.br/fsp/cotidian/ff29039817.htm> Acesso em 14 jun. 2020.

GREEN, James N. Revolucionário e gay: a vida extraordinária de Herbert Daniel pioneiro na luta pela democracia, diversidade e inclusão. $1^{\text {a }}$ ed., Rio de Janeiro: Civilização Brasileira, 2018.

IRE, Binah; LENZI, Maria Helena; SILVA, Camila Diane. Ser lésbica na ditadura: vida e militância sob Estado de exceção. In: MELLO, Soraia Carolina de; WOLFF, Cristina Scheibe; ZANDONÁ, Jair (orgs.). Mulheres na Luta: feminismo e esquerdas no Brasil (1964 - 1985). Curitiba: Appris, 2019.

MUSEU DA DIVERSIDADE SEXUAL. Memórias da Diversidade Sexual: Marisa Fernandes (parte 4/5). São Paulo, 2017. Disponível em: $<$ https://www.youtube.com/watch?v=NQuymeabnTg $>$ Acesso em 14 jun. 2020.

OLIVEIRA, Luana Farias. Quem tem medo de sapatão? Resistência lésbica à Ditadura Civil-Militar (1964-1985). Revista Periódicus, v.1, n.7, 2017. Disponível em: 
$<$ https://portalseer.ufba.br/index.php/revistaperiodicus/article/view/21694> Acesso em:

28 mai. 2020.

PACOR, Mariana. Quantas lésbicas cabem num fusquinha? Expressão de memória, aglutinação e resistência. Revista Tia Concha, n. 1. São Paulo, 2018, p. 10-15.

PAIVA, Marcelo Rubens. Literatura de Cassandra Rios educou uma geração. Folha de S. Paulo. 16 mar. 2002. Disponível em: $<$ https://www1.folha.uol.com.br/folha/ilustrada/ult90u22181.shtml $>$ Acesso em 12 jun. 2020 .

PEREZ, Lívia (no prelo). Do Cinema Novo ao vídeo lésbico feminista: a trajetória de Norma Bahia Pontes. Revista brasileira de estudos de cinema e audiovisual, n. 18, jul$\operatorname{dez} 2020$.

RIOS, Cassandra. Eu sou uma lésbica. Rio de Janeiro: Azougue Ed., 2006 [1979] (Coleção Devassa).

RODRIGUES, Nelson. Vestido de Noiva. In: RODRIGUES, Teatro completo - Nelson Rodrigues. v. 1, 4⿳a ed.. Rio de Janeiro: Editora Nova Fronteira, 2017 [1943], p. 158-275. Álbum de Família. In: RODRIGUES, Teatro completo - Nelson Rodrigues. v. 1, 4 ${ }^{\mathrm{a}}$ ed.. Rio de Janeiro: Editora Nova Fronteira, 2017 [1946], p. 555-676.

SACRAMENTO, Evelyn dos Santos. Adélia Sampaio, uma cineasta que ousou ser. Seminário Internacional Fazendo Gênero 11 \& 13th Women's Worlds Congress (Anais Eletrônicos), Florianópolis, 2017, p. 1-10.

SALES, Gabriela Coutinho. Lésbicas no debate da redemocratização: uma análise do boletim Chanacomchana. Trabalho de Conclusão de Curso. Departamento de História, Instituto de Ciências Humanas, Universidade de Brasília. Brasília: 2019.

SILVA, José Afonso. Curso de Direito Constitucional Positivo. $37^{\mathrm{a}}$ ed. SP: Malheiros, 2014. 
SOARES, Gilberta S.; COSTA, Jussara C. Movimento lésbico e Movimento feminista no

Brasil: recuperando encontros e desencontros. Labrys, estudos feministas, jul./dez. 2011 - jan./jun. 2012.

UM OUTRO OLHAR. Retrospectiva das famosas que saíram do armário: de Angela Roro a Maria Gadu, 05 dez. 2013. Disponível em: $<$ http://www.umoutroolhar.com.br/2013/12/retrospectiva-das-famosas-que-sairamdo.html> Acesso em 15 jun. 2020.

USP, Canal. LGBTs no Regime Militar - As mídias alternativas. 2018. (5min42). Disponível em: <https://www.youtube.com/watch?v=FmfbxmVMVmM\&t=203s> Acesso em 30 mai. 2020.

LGBTs no Regime Militar - A primeira passeata. (5min46). Disponível em: $<$ https://www.youtube.com/watch?v=vS8qi_oDkGE $>$ Acesso em 30 mai. 2020.

\section{Lesbianities in Sao Paulo (1940-2000)}

\section{A brief overview}

Abstract: This article aims to investigate the emergence and consolidation of the lesbian movement in Sao Paulo, starting from some historical milestones in the artistic, journalistic, social and political fields that go from 1940 to the beginning of the $2000 \mathrm{~s}$. It also aims to contribute to the increase in the production and dissemination of information about the context in which part of the reproduction of the imaginary about lesbianity took place and the constitution of lesbians as a socio-political subject in the urban space. The text was constructed using primary sources (newspaper articles, artistic works), publications of interviews with militants and academic productions on the topics covered. Keywords: Lesbianities; Imaginary; History; Collective agency; Social struggles.

\section{Lesbianidades en São Paulo (1940-2000):}

Breve panorama

Resumen: Este artículo tiene como objetivo investigar el surgimiento y consolidación del movimiento lésbico en São Paulo, a partir de algunos hitos históricos en los campos artístico, periodístico, social y político que van desde 1940 hasta principios de la década del 2000. Tiene aún como intento contribuir al aumento de la producción y difusión de información sobre el contexto en el que se produjo parte de la reproducción del imaginario sobre la lesbianidad y la constitución de las lesbianas como sujetos sociopolíticos en el 


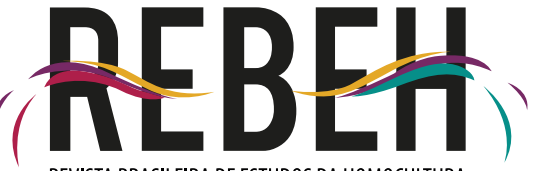 \\ REVISTA BRASILEIRA DE ESTUDOS DA HOMOCULTURA}

espacio urbano. El texto se construyó a partir de fuentes primarias (artículos periodísticos, trabajos artísticos), publicaciones de entrevistas a militantes y producciones académicas sobre los temas tratados.

Palabras clave: Lesbianidades; Imaginario; Historia; Sujeto colectivo; Luchas sociales.

Recebido: 16/12/2020

Aceito: 17/02/2021 